\title{
Sub-Chronic Oral Toxicity Study of Pseudocedrela Kotschyi Ethanol Leaf Extract in Wistar Rats
}

\author{
Ezeokpo BC ${ }^{1}$, Akuodor $\mathrm{GC}^{2,3 *}$, Erejuwa $\mathrm{OO}^{3}$, Akpan $\mathrm{JL}^{4,3}$, Nnolim $\mathrm{BI}^{1}$, Eze $\mathrm{CO}^{1}$, Nwobodo $\mathrm{MU}^{1}$, Ezeonu $\mathrm{CT}^{5}$ \\ ${ }^{1}$ Department of Internal Medicine, Faculty of Medicine, Ebonyi State University, Abakaliki, Nigeria \\ ${ }^{2,3}$ Department of Pharmacology and Therapeutics, Faculty of Medicine, Nnamdi Azikiwe University, Nnewi Campus, Nigeria \\ ${ }^{3}$ Department of Pharmacology and Therapeutics, Faculty of Medicine, Ebonyi State University, Abakaliki, Nigeria \\ ${ }^{4,3}$ Department of Pharmacology, Faculty of Basic Medical Sciences, College of Medical Sciences, University of Calabar, Nigeria \\ ${ }^{5}$ Department of Peadiatrics, Faculty of Medicine, Ebonyi State University, Abakaliki, Nigeria
}

DOI:10.36348/SJMPS.2019.v05i09.005

| Received: 20.08.2019 | Accepted: 27.08.2019 | Published: 21.09.2019

*Corresponding author: Dr. Akuodor Godwin C

\section{Abstract}

The leaves of Pseudocedrela. kotschyi are used in herbal medicine in Sub-Saharan Africa without safety concerns. Determination of its safety profile will provide supportive scientific evidence in favour of its continuous usage. To evaluate the sub-chronic toxicity activity of the ethanol extract of Pseudocedrela. Kotschyi leaves. Sub-chronic toxicity evaluation of the extract was determined by administering $100 \mathrm{mg} / \mathrm{kg}, 200 \mathrm{mg} / \mathrm{kg}$ and $400 \mathrm{mg} / \mathrm{kg}$ on Wistar rats for 40 days with distilled water as control. The haematological and biochemical parameter as well as the relative organ weights were examined. In the 40 days sub-chronic oral toxicity study, administration of $100 \mathrm{mg} / \mathrm{kg}, 200 \mathrm{mg} / \mathrm{kg}$ and $400 \mathrm{mg} / \mathrm{kg}$ of $P$. kotschyi leaf extract per body weight showed significant $(\mathrm{p}<0.05)$ body weight change, significant $(\mathrm{p}<0.05$ and $\mathrm{p}<0.01)$ changes in some haematological and biochemical parameters and organ weights compared to the control group. Analyses of these results could lead to the conclusion that the oral administration of $P$. kotscyi leaf extract for 40 days does not cause sub-chronic toxicity in rats

Keywords: Pseudocedrela kotschyi, Maliaceae, Subchronic toxicity, Leaf extract, Herbal medicine, Rats.

Copyright @ 2019: This is an open-access article distributed under the terms of the Creative Commons Attribution license which permits unrestricted use, distribution, and reproduction in any medium for non-commercial use (NonCommercial, or CC-BY-NC) provided the original author and source are credited.

\section{INTRODUCTION}

Medicinal plants have been used for decades as remedies for human diseases. Most of these natural products have strong scientific evidence with regard to their biological activities. However, little information is available regarding the possible toxicity that medicinal plants may cause to the end users [1]. Based on the long-term use of medicinal plants by humans, one might expect these plants to have low toxicity. Nevertheless, recent surveys have indicated that numerous medicinal plants applied in traditional medicine exhibited adverse effects [2, 3]. Hence, it should be emphasized that the traditional use of any plant for medicinal purposes must guarantee the safety of such plant. This calls for concern about the important toxic effects emanating from the short-term and longterm use of such medicinal plants. The values of the acute, sub-acute and sub-chronic toxicity investigations on medicinal plants should be obtained to increase the confidence in their safety to humans, especially for use in the development of pharmaceuticals products [4].
Pseudocedrela kotschyi Schweint. Harms which belonging to the family Meliaceae is a tree of up to 20 metres high with a wide crown fissured bark and fragrant white flowers. $P$. kotschyi is a very popular herb amongst practitioners of traditional medicine and is widely used as a decoction or infusion to treat various diseases. The antmalaria, antipyretic, dental cleaning, analgesic and anti-inflammatory, antibacterial and antiepileptic [5-11] activities of different extracts of the plant have been scientifically investigated and reported. The acute and sub-acute toxicity profiles of the plant leaf extract has also been reported [12]. Based on $P$. kotschyi use in herbal medicine practices and the literature references, the present study was undertaken to evaluate the sub-chronic toxicity in rats after oral dosing for 40 days.

\section{MATERIALS AND METHODS \\ Plant material collection}

The fresh leaves of P. kotschyi were collected from Niger State, Nigeria. Plant identification and authentication was done by a taxonomist in the 
Department of Medicinal Plant research and Traditional Medicine, NIPRD, Abuja, Nigeria. Voucher specimen (NIPRD/H/6542) was deposited in the herbarium of the Institute.

\section{Extraction}

The fresh leaves were rinsed thoroughly in distilled water and air-dried until a constant weight was maintained. The dried plant material was ground to fine powder and soaked in absolute ethanol (450 g in $2.5 \mathrm{~L})$ with constant agitation. The extract was filtered $24 \mathrm{~h}$ later. The filtrate was evaporated to dryness on a water bath under reduced pressure, giving a dark brown solid with a yield of $17.65 \%$. The dried extract was stored in a refrigerator at $4^{0} \mathrm{C}$ and later reconstituted in distilled water before administration to experimental animals.

\begin{abstract}
Animals
Male and female Wistar rats used for this study were purchased from animal house unit, Enugu, Nigeria. The animals were acclimatized for at least 14 days. Six rats were housed per cage (male and female rats were kept separate) and maintained in a wellventilated animal room with temperature of $25-27{ }^{0} \mathrm{C}$ and 12-h light/dark cycle. The animals had free access to rodent pellet and portable water ad libitum. The rats were handled with humane care and in accordance with Institutional guidelines of Ethics Committee of Ebonyi State University (EBSU/UREC/TETFUND/15/14) and international accepted principles for laboratory animal use and care [13].
\end{abstract}

\section{Sub-chronic toxicity study}

Wistar rats of either sex weighing between 170-200 $\mathrm{g}$ were used for this study and evaluation of sub-chronic toxicity was performed as the methods described by OECD guidelines 407 [14]. The animals were fed with standard pellet and had water ad libitum. The rats were randomly allotted to four groups of 6 animals each. The Group I rats served as control and was administered $0.2 \mathrm{~mL}$ of distilled water via the oral route. Group 2, 3 and 4 received an ethanol extract of P. kotschyi leaf orally at doses of $100 \mathrm{mg} / \mathrm{kg}, 200$ $\mathrm{mg} / \mathrm{kg}$ and $400 \mathrm{mg} / \mathrm{kg}$ daily for 40 days.

\footnotetext{
Animal observation

All animals were weighed individually immediately before dosing on day one and thereafter, once a week. All animals were observed daily for mortality, general condition, and clinical signs of toxicity before the test and throughout the dosing period. Clinical observations including motor activity, appearance, central and autonomic functions were performed once a week. Daily food consumption was measured before the initiation of dosing and once a week thereafter. Food consumption was calculated by subtracting the amount of leftover feed from the total feed provided.
}

\section{Haematology and serum biochemistry}

On day 40, animals were fasted overnight and then sacrificed the following day under inhaled chloroform anaesthesia. Blood samples were collected via cardiac puncture [15] for determination of routine haematological and serum biochemistry analysis.

Haematology measurements (Mythic 18 automated haematology analyzer by Orphee, Switzerland) included the following: Red blood cell count (RBC), hemoglobin concentration (HB), packed cell volume (PCV), mean cell volume (MCV), mean cell hemoglobin $(\mathrm{MCH})$, mean cell hemoglobin concentration (MCHC), platelet count (PLT), white blood cell count (WBC), WBC differential count (neutrophil, lymphocyte and monocyte ratio).

Serum biochemistry analysis (Gesan Chem 200, USA) included: alanine aminotransferase (ALT), aspartate aminotransferase (AST), alkaline phosphatase (ALP), blood urea nitrogen (BUN),creatinine (Crea), albumin (ALB), total protein (TP), total cholesterol ( $\mathrm{T}$ Chol), triglyceride (TG) and high density lipoprotein (HDL) of the samples were determined.

\section{Organ weight measurement}

Following the sacrifice, qualitative data on the weights of vital organs (heart, lungs, liver, kidneys and testes) were assessed by carefully dissecting each organ from sacrificed animal. The isolated organs were dried with cotton wool and weighed on a sensitive balance. Each weighed organ was standardized for $100 \mathrm{~g}$ body weight of each rat [16].

\section{STATISTICAL ANALYSIS}

The data were analyzed using SPSS version 16. Data are expressed as mean \pm SEM. $\mathrm{P}$ value $<0.05$ was considered significant. One-way analysis of variance (ANOVA) and post hoc Tukey's test were used to identify differences among the groups.

\section{RESULTS}

\section{Effect of the ethanol leaf extract on body weight}

Table 1 showed the leaf extract compared to the control, caused significant increase in the percentage body weight in a dose dependent manner with the highest increase recorded at the dose of 100 and $200 \mathrm{mg} / \mathrm{kg}$ during the 40 days treatment.

\section{Effect of the ethanol leaf extract on haematological parameters in 40-day study}

Table 2 shows a non-significant $(\mathrm{p}>0.05)$ increase in $\mathrm{RBC}$ and $\mathrm{HB}$ compared to the control, whereas PLT and WBC MCV showed a significant $(p<0.05)$ increase when compared to control. There was a decrease level of MCV except at $400 \mathrm{mg} / \mathrm{kg}$ where a significant $(\mathrm{p}<0.01)$ was observed compared to control. The results also showed a non-significant $(p>0.05)$ 
decrease in $\mathrm{MCH}$ compared to the control, while a significant decrease was observed in MCHC compared to the control. The lymphocytes and neutrophils percentage $(\%)$ showed a significant $(\mathrm{p}<0.01)$ increase in the group of animals administered $100 \mathrm{mg} / \mathrm{kg}, 200$ $\mathrm{mg} / \mathrm{kg}$ and $400 \mathrm{mg} / \mathrm{kg}$, while the monocytes percentage $(\%)$ showed a significant $(\mathrm{p}<0.05)$ at $200 \mathrm{mg} / \mathrm{kg}$ and $400 \mathrm{mg} / \mathrm{kg}$ compared to the control. The PCV showed a significant $(\mathrm{p}<0.01)$ increase at both $200 \mathrm{mg} / \mathrm{kg}$ and 400 $\mathrm{mg} / \mathrm{kg}$ compared with the control.

Effect of the ethanol leaf extract on serum biochemical parameters in 40-day study

The data in Table 3 show the effects of ethanol root bark extract on liver enzymes and lipid profile. Asparatate transaminase (AST) levels show a significant $(\mathrm{p}<0.05)$ increase in all the treated groups when compared to the control. However, there was a statistical significant $(\mathrm{p}<0.01)$ increase in alanine transferase (ALT) levels in all the treated groups when compared to the control. Alkaline phosphatase (ALP) and albumin levels showed statistically significant $(\mathrm{p}<0.01$ and $\mathrm{p}<0.05)$ increases respectively, when compared to the control. In the lipid profile study, there was significant decrease in levels of total cholesterol ( $\mathrm{T}$ Chol) while increase in triglycerides (TG) levels was observed in the treated groups compared to the control. There was non-significant $(p>0.05)$ increase in the levels of High Density Lipoprotein (HDL) observed when compared to the control.

Effect of the ethanol leaf extract on serum electrolytes, urea and creatinine in 40-day study

The leaf extract of $P$. kotschyi did not show any significant $(\mathrm{p}>0.05)$ activity on the serum electrolytes, sodium, potassium, bicarbonate and urea after administration of the extract for 40 days except significant $(\mathrm{p}<0.05$ and $\mathrm{p}<0.01)$ non-dose dependent increase in creatinine and chloride levels in treated rats compared to the control (Table 4).

\section{Effect of the ethanol leaf extract on weights of organ of rats per $100 \mathrm{~g}$ body weight}

There were statistical significant $(\mathrm{p}<0.05$ and $\mathrm{p}<0.01)$ dose dependent in the weight of the organs (liver, kidneys, lungs and spleen), but there was no significant $(\mathrm{p}>0.05)$ difference in the weight of the organ (heart) per $100 \mathrm{~g}$ body weight when compared with control (Table 5).

Table-1: Effect of the extract on body weight of rats after 40 days of sub-chronic toxicity study Dose (mg/kg) Percentage weight change

\begin{tabular}{|l|l|}
\hline Control & $\mathbf{6 7 . 8 5} \pm \mathbf{4 . 7 9}$ \\
\hline 100 & $82.50 \pm 5.69$ \\
\hline 200 & $87.44 \pm 6.57$ \\
\hline 400 & $79.65 \pm 4.34$ \\
\hline
\end{tabular}

Results are presented as Mean \pm SEM $(n=6)$

Table-2: Effect of the extract on haematological parameters in rats after 40 days sub-chronic toxicity study

\begin{tabular}{|c|c|c|c|c|}
\hline \multicolumn{5}{|c|}{ Dose (mg/kg) } \\
\hline Parameter & Control & 100 & 200 & 400 \\
\hline Red blood cells (x10 $12 / \mathrm{L})$ & $5.91 \pm 0.27$ & $4.92 \pm 0.16$ & $5.65 \pm 0.25$ & $4.65 \pm 0.40$ \\
\hline Haemoglobin $(\mathrm{g} / \mathrm{dL})$ & $10.77 \pm 0.58$ & $12.40 \pm 0.47$ & $12.30 \pm 0.43$ & $12.45 \pm 0.66$ \\
\hline Mean corpuscular volume (fl) & $61.38 \pm 0.63$ & $60.63 \pm 1.17$ & $61.88 \pm 0.35$ & $68.27 \pm 0.78 * *$ \\
\hline Mean cell haemoglobin $(\mathrm{pg})$ & $21.38 \pm 0.21$ & $21.67 \pm 0.36$ & $21.20 \pm 0.27$ & $21.22 \pm 0.35$ \\
\hline Mean cell haemoglobin concentration $(\mathrm{g} / \mathrm{dl})$ & $39.50 \pm 0.63$ & $35.22 \pm 0.66$ & $34.33 \pm 0.46$ & $34.72 \pm 0.46$ \\
\hline Pack cells volume $(\%)$ & $30.57 \pm 1.83$ & $33.35 \pm 2.26$ & $38.53 \pm 1.54 * *$ & $37.19 \pm 2.86^{* *}$ \\
\hline Platelet count $\left(\times 10^{9} / \mathrm{L}\right)$ & $304.17 \pm 37.64$ & $313.67 \pm 38.67$ & $322.17 \pm 28.66$ & $328.75 \pm 54.82$ \\
\hline White blood cells $\left(\times 10^{9} / \mathrm{L}\right)$ & $3.95 \pm 0.64$ & $4.88 \pm 0.64$ & $4.47 \pm 0.68$ & $4.65 \pm 0.40$ \\
\hline Lymphocytes (\%) & $67.52 \pm 1.39$ & $84.83 \pm 1.33 * *$ & $82.83 \pm 2.83 * *$ & $84.00 \pm 2.86 * *$ \\
\hline Neutrophils (\%) & $6.00 \pm 1.18$ & $11.00 \pm 1.22 * *$ & $13.33 \pm 1.94 * *$ & $11.83 \pm 1.80 * *$ \\
\hline Monocytes (\%) & $4.17 \pm 0.65$ & $4.17 \pm 0.39$ & $5.83 \pm 0.39 *$ & $5.95 \pm 0.38 *$ \\
\hline
\end{tabular}

Results are presented as Mean \pm SEM $(n=6) ;{ }^{*} p<0.05$ compared to the control; $* * p<0.01$ compared to the control.

Table-3: Effect of extract on serum biochemical parameters in rats after 40 days of sub-chronic toxicity study

\begin{tabular}{|l|l|l|l|l|}
\hline \multicolumn{5}{|c|}{ Dose $(\mathbf{m g} / \mathbf{k g})$} \\
\hline Parameter & Control & $\mathbf{1 0 0}$ & $\mathbf{2 0 0}$ & $\mathbf{4 0 0}$ \\
\hline Aspartate transaminase (U/L & $60.48 \pm 5.34$ & $64.52 \pm 6.10$ & $63.66 \pm 5.25$ & $66.84 \pm 8.48^{*}$ \\
\hline Alanine transaminase (U/L) & $43.19 \pm 3.48$ & $45.67 \pm 4.32$ & $43.9 \pm 3.92$ & $44.64 \pm 4.63$ \\
\hline Alkaline phosphatase (U/L) & $102.80 \pm 6.11$ & $120.55 \pm 8.57^{* *}$ & $110.62 \pm 9.46^{*}$ & $108.71 \pm 10.38^{*}$ \\
& & & & \\
\hline Albumin (mg/dL) & $6.36 \pm 0.50$ & $70.52 \pm 0.46^{*}$ & $6.89 \pm 0.48$ & $6.95 \pm 0.39$ \\
\hline Total cholesterol (mg/dL) & $134.20 \pm 11.42$ & $128.49 \pm 9.19$ & $120.64 \pm 10.60$ & $118.56 \pm 10.20$ \\
\hline Triglycerides (mg/dL) & $54.43 \pm 7.15$ & $72.44 \pm 7.63^{* *}$ & $66.56 \pm 8.42^{*}$ & $61.72 \pm 8.55^{*}$ \\
\hline HDL Cholesterol (mg/dL) & $38.43 \pm 0.38$ & $38.64 \pm 0.67$ & $37.92 \pm 0.55$ & $37.84 \pm 0.88$ \\
\hline
\end{tabular}

Results are presented as Mean \pm SEM $(n=6) ;{ }^{*} \mathrm{p}<0.05$ compared to the control; ${ }^{* * *} \mathrm{p}<0.01$ compared to the control. 
Table-4: Effect of the extract on serum electrolytes, urea and creatinine in rats after $\mathbf{4 0}$ days sub-chronic toxicity study

\begin{tabular}{|l|l|l|l|l|}
\hline \multicolumn{5}{|c|}{ Dose $(\mathbf{m g} / \mathbf{k g})$} \\
\hline Parameter & Control & $\mathbf{1 0 0}$ & $\mathbf{2 0 0}$ & $\mathbf{4 0 0}$ \\
\hline Sodium $(\mathrm{meq} / \mathrm{L})$ & $147.77 \pm 3.52$ & $148.47 \pm 3.66$ & $148.40 \pm 4.18$ & $146.87 \pm 4.38$ \\
\hline Potassium $(\mathrm{meq} / \mathrm{L})$ & $5.15 \pm 0.51$ & $5.55 \pm 0.76$ & $5.77 \pm 0.82$ & $5.10 \pm 0.66$ \\
\hline Chloride $(\mathrm{meq} / \mathrm{L})$ & $108.54 \pm 3.65$ & $115.69 \pm 5.69^{* *}$ & $113.71 \pm 4.75^{* *}$ & $111.89 \pm 5.28^{*}$ \\
\hline Bicarbonate $(\mathrm{meq} / \mathrm{L})$ & $34.85 \pm 1.44$ & $35.68 \pm 2.29$ & $34.95 \pm 1.53$ & $35.76 \pm 1.66$ \\
\hline Urea $(\mathrm{mg} / \mathrm{dl})$ & $28.47 \pm 4.60$ & $28.69 \pm 3.66$ & $27.55 \pm 3.42$ & $27.88 \pm 3.76$ \\
\hline Creatinine $(\mathrm{mg} / \mathrm{dl})$ & $0.80 \pm 0.14$ & $0.89 \pm 0.17$ & $1.02 . \pm 0.22^{*}$ & $0.90 \pm 0.33^{*}$ \\
\hline
\end{tabular}

Results are presented as Mean \pm SEM $(n=6) ; ~ p<0.05$ compared to the control; ${ }^{* *} \mathrm{p}<0.01$ compared to the control

Table-5: Effect of the extract on rat relative organ weights after 40 days sub-chronic toxicity study Dose (mg/kg)

\begin{tabular}{|l|l|l|l|l|}
\hline Organs (g) & Control & $\mathbf{1 0 0}$ & $\mathbf{2 0 0}$ & $\mathbf{4 0 0}$ \\
\hline Liver & $8.49 \pm 0.53$ & $6.64 \pm 0.34 *$ & $4.55 \pm 0.17^{* *}$ & $4.72 \pm 0.26^{* *}$ \\
\hline Kidneys & $1.13 \pm 0.67$ & $0.95 \pm 0.17$ & $0.65 \pm 0.63^{* *}$ & $0.76 \pm 0.14^{* *}$ \\
\hline Heart & $0.66 \pm 0.44$ & $0.66 \pm 0.88$ & $0.56 \pm 0.62$ & $0.56 \pm 0.64$ \\
\hline Lungs & $1.48 \pm 0.17$ & $1.65 \pm 0.64$ & $1.66 \pm 0.29$ & $1.21 \pm 0.23^{* *}$ \\
\hline Spleen & $0.68 \pm 0.06$ & $0.69 \pm 0.68$ & $0.55 \pm 0.66^{*}$ & $0.57 \pm 0.67 *$ \\
\hline
\end{tabular}

Results are presented as Mean \pm SEM $(n=6) ;{ }^{*} \mathrm{p}<0.05$ compared to the control; ${ }^{* *} \mathrm{p}<0.01$ compared to the control.

\section{DISCUSSION}

Medicinal plants mostly contain highly potent pharmaceutical constituents which has actually been the basis for the treatment of different diseases [17]. Although, P. kotschyi leaf extract contains bioactive compounds with potential to cause either beneficial or detrimental effects, which makes it imperative to carry out toxicity study to ascertain its safety and efficacy. The aim of evaluating the safety profile of any herbal agent is to identify the significant nature and the leaf extract adverse effects, also to determine the exposure level where the effect is noticed.

Variations in body weight are sensitive parameters of effects of chemicals and drugs [18]. Daily administration of the ethanol leaf extract for 40 days showed significant changes in body weight gain in extract treated rats compared to the control. The observed results showed that there was effect on rats' normal growth at the treatment of the sub-chronic oral doses of $P$. kotschyi ethanol leaf extract. The various investigated haematological indices are important parameters that can be studied to assess the toxic effect of plant extracts in both human and animals [19]. The $\mathrm{RBC}$ and $\mathrm{HB}$ are very important in transferring respiratory gases, and their non-significant effect in the test groups when compared to the control shows that there was not much change in the oxygen carrying capacity of the blood and the amount of oxygen carried to the tissues due to treatment with different doses of the leaf extract to the test animals. There was significant increase in PCV at the highest dose (400 $\mathrm{mg} / \mathrm{kg}$ ) in the test groups at all doses of the treated extract of $P$. kosctyii leaf when compared to control.

$\mathrm{MCV}, \mathrm{MCH}$ and $\mathrm{MCHC}$ have been reported to be significant in diagnosing anaemia in animals and human red blood cells [20, 21]. The non-significant effect of the leaf extract at the treated doses on RBC and some of its indices ( $\mathrm{HB}, \mathrm{MCH}$ and $\mathrm{MCHC})$ in the study could be an indication that there was no destruction of RBCs. Furthermore, this observation might equally be shown to the fact that the correlation between the production rate and destruction of the corpuscles was not significantly altered by the extract. The result also show that the leaf extract does not possess the potential to stimulate the release of erythropoietin in the kidney which is the regulator of RBC production [22, 23].

A decrease in platelet count in laboratory animals has been reported to indicate an adverse effect on the oxygen-carrying capacity of the blood as well as on thrombopoietin [24]. However, it was on the contrary in the present study as an increase in platelets was observed in the test groups compared to the control. The observed result may be due to the stimulatory effect of the extract on thrombopoietin.

However, the significant $(\mathrm{p}<0.05)$ increase observed in WBC following the administration of the plant extract may be due to increase in vascular permeability. Results also showed that other indices that relate to WBC (neutrophils, lymphocytes and monocytes) were significantly increased in the test groups compared to the control group. The lymphocytes are believed to be main effector cells of the immune system and the observed increase in the test groups compared to the control in this study may specifically be ascribed to the ability of the extract to stimulate neutrophils to promote phagocytosis [25]. High neutrophil counts can be the result of many factors that include bacterial infection, acute inflammation, stress 
response effect from some drugs and splenectomy, among others [26].

Alanine aminotransferase (ALT) and aspartate aminotransferase (AST) have been determined to be markers of hepatocellular injury while alkaline phosphatase (ALP) is a marker of cholestasis [27]. Of the two, increase in ALT levels is a more specific indicator of liver injury because ALT catalyses the conversion of alanine to pyruvate and glutamate and is released in a similar manner. A non-significant decrease in AST, significant $(\mathrm{p}<0.001)$ decrease in ALT levels, as well as an insignificant $(\mathrm{p}>0.05)$ increase in ALP levels was observed in the test groups compared to the control. It is possible to speculate that this observed effect of the extract was due to its ability to stabilize the plasma membrane and may be a potential in modulating the exogenous toxic effects of agents on liver cells. The serum ALP levels are also related to the status and function of hepatic cells and according to the literature, an increase in serum ALP may occur as a result of increased synthesis, in the presence of increasing biliary pressure.

Determination of serum electrolytes, Urea and Creatinine are important markers of kidney function and elevations in the levels of these parameters are indicative of kidney injury [28, 29]. The extract caused significant increase in Chloride and creatinine with no observable significant changes in other serum electrolytes and blood urea parameters in the treated compared to control rats. These results indicated that the plant extract has no toxic effect on the kidneys.

Generally, reduction in internal weight of an organ is an indication of toxicity due to exposure to toxic substances [30]. In respect to the vital organs, significant changes in weight were observed in the liver, kidneys, lungs and spleen in the 40 days treatment period except for a no significant decrease in weight of the heart. The observed increase in weight of the liver, kidneys, lungs and spleen in sub-chronic study may however be attributed to unknown cause.

In conclusion, the findings from this study provide valuable data on the sub-chronic oral toxicological profile of P.kotschyi leaf extract. The plant has been reported to be non-toxic on acute exposure [12]. Further study on the chronic toxicity is needed to fully ascertain the safety profile of $P$. kotschyi leaf extract.

\section{TRANSPARENCY DECLARATION}

The authors declare that there is no conflict of interest.

\section{ACKNOWLEDGMENTS}

This project was supported by funding from Tertiary Education Trust Fund (TETFund) administered by the Directorate of Research, Innovation \& Commercialization, Ebonyi State University, Abakaliki, (Ref No. EBSU/TETFund/IBR/15/14). The authors are grateful to Mr. Simon Eze Nwibo and Chibueze Nwonu for their technical assistance.

\section{REFERENCES}

1. Saxena, G., Mittal, A., \& Siddiqui, A. W. (2019). Evaluation of acute and subchronic toxicity of dragon blood resin extract. Journal of Drug Delivery and Therapeutics, 9(2), 362-366.

2. Ertekin, V., Selimoğlu, M. A., \& Altinkaynak, S. (2005). A combination of unusual presentations of Datura stramonium intoxication in a child: Rhabdomyolysis and fulminant hepatitius. Journal of Emergency Medicine, 28(2), 227-228.

3. Koduru, S., Grierson, D. S., \& Afolayan, A. J. (2006). Antimicrobial Activity of Solanum aculeastrum. Pharmaceutical biology, 44(4), 283286.

4. Ukwuani, A. N., Abubakar, M. G., Hassan, S. W., \& Agaie, B. M. (2012). Toxicological studies of hydromethanolic leaves extract of Grewia crenata. Int J Pharm Sci Drug Res, 4(4), 245-9.

5. Akuodor, G. C., Ajoku, G. A., Ezeunala, M. N., Chilaka, K. C., \& Asika, E. C. (2015). Antimalarial potential of the ethanolic leaf extract of Pseudocedrala kotschyi. Journal of Acute Disease, 14, 23-27.

6. Kassim, O. O., Loyevsky, M., Amonoo, H., Lashley, L., Ako-Nai, K. A., \& Gordeuk, V. R. (2009). Inhibition of in-vitro growth of Plasmodium falciparum by Pseudocedrela kotschyi extract alone and in combination with Fagara zanthoxyloides extract. Transactions of the Royal Society of Tropical Medicine and Hygiene, 103(7), 698-702.

7. Akuodor, G. C., Essien, A. D., Essiet, G. A., David-Oku, E., Akpan, J. L., \& Udoh, F. V. (2013). Evaluation of antipyretic potential of Pseudocedrela kotschyi Schweint. Harms (Meliaceae). European Journal of Medicinal Plants, 3(1), 105.

8. Tapsoba, H., \& Deschamps, J. P. (2006). Use of medicinal plants for the treatment of oral diseases in Burkina Faso. Journal of Ethnopharmacology, 104(1-2), 68-78.

9. Musa, Y. M., Haruna, A. K., Ilyas, M., Yaro, A. H., Ahmadu, A. A., \& Usman, H. (2005, May). Analgesic and antiinflammatory activities of the leaves of Pseudocedrela kotschyi Harms (Meliaceae). In Book of Abstracts of the 23rd National Scientific Conference of the Nigerian Society of Pharmacognosy (pp. 88-89).

10. Kone, W. M., Atindehou, K. K., Terreaux, C., Hostettmann, K., Traore, D., \& Dosso, M. (2004). Traditional medicine in North Côte-d'Ivoire: screening of 50 medicinal plants for antibacterial 
activity. Journal of ethnopharmacology, 93(1), 4349.

11. Anuka, J. A., Ijezie, D. O., \& Ezebnik, O. N. (1999). Investigation of Pharmacological actions of the extract of the extract Pseudocedrela kotschyi in Laboratory animals. In proceedings of XXVIIth Annual Regional conference of WASP(pp. 9-10).

12. Ezeokpo, B.C., Akuodor, G.C., Erejuwa, O.O., Akpan, J.L., Nnolim, B.I., Ogiji, E.D., Nwobodo, M.U., Ezeonu, C.T.(2018). Acute and sub-acute toxicity studies of Pseudocedrela kotschyi ethanolic leaf extract in Wistar rats. Asian Pac. Journal of Med. Toxicol. (in press).

13. NIH.(2011). Guide for the Care and Use of Laboratory Animals. 8th ed. Bethesda MD: National Institutes of Health, 82-83

14. OECD.(2008). OECD Guideline for Testing of Chemicals (TG 407). Repeated Dose 28-Day Oral Toxicity Study in Rodents. OECD/OEDC.

15. Manaharan, T., Chakravarthi, S., Radhakrishnan, A. K., \& Palanisamy, U. D. (2014). In vivo toxicity evaluation of a standardized extract of Syzygium aqueum leaf. Toxicology reports, 1, 718-725.

16. Mbaka, G. O., Adeyemi, O. O., \& Oremosu, A. A. (2010). Acute and sub-chronic toxicity studies of the ethanol extract of the leaves of Sphenocentrum jollyanum (Menispermaceae). Agriculture and Biology Journal of North America, 1(3), 265-272.

17. Wang, L., Li, Z., Li, L., Li, Y., Yu, M., Zhou, Y., ... \& Xu, Y. (2014). Acute and sub-chronic oral toxicity profiles of the aqueous extract of Cortex Dictamni in mice and rats. Journal of ethnopharmacology, 158, 207-215.

18. Santos, S. R., Rangel, E. T., Lima, J. C. S., Silva, R. M., Lopes, L., Noldin, V. F., ... \& Martins, D. T. O. (2009). Toxicological and phytochemical studies of Aspidosperma subincanum Mart. stem bark (Guatambu). Die Pharmazie-An International Journal of Pharmaceutical Sciences, 64(12), 836839.

19. Sunmonu, T. O., \& Oloyede, O. B. (2010). Performance and haematological indices in rats exposed to monocrotophos contamination. Human \& experimental toxicology, 29(10), 845-850.

20. Coles, E.H. (1986). Veterinary Clinical Pathology, W.B Saunders, Philadelphia, USA, 10-42
21. Ashafa, A. O. T., Sunmonu, T. O., \& Afolayan, A. J. (2011). Effects of leaf and berry extracts of Phytolacca dioica L. on haematological and weight parameters of Wistar rats. African Journal of Pharmacy and Pharmacology, 5(2), 150-154.

22. Polenakovic, M., \& Sikole, A. (1996). Is erythropoietin a survival factor for red blood cells?. Journal of the American Society of Nephrology, 7(8), 1178-1182.

23. Sánchez-Elsner, T., Ramírez, J. R., RodriguezSanz, F., Varela, E., Bernabéu, C., \& Botella, L. M. (2004). A cross-talk between hypoxia and TGF- $\beta$ orchestrates erythropoietin gene regulation through SP1 and Smads. Journal of molecular biology, 336(1), 9-24.

24. McLellan, S. A., McClelland, D. B. L., \& Walsh, T. S. (2003). Anaemia and red blood cell transfusion in the critically ill patient. Blood reviews, 17(4), 195-208.

25. McKnight, D. C., Mills, R. G., Bray, J. J., \& Crag, P. A. (1999). Human physiology. Churchill Livingstone.

26. Owoseni, A. A., Ayanbamiji, T. A., Ajayi, Y. O., \& Ewegbenro, I. B. (2010). Antimicrobial and phytochemical analysis of leaves and bark extracts from Bridelia ferruginea. African Journal of Biotechnology, 9(7), 1031-1036.

27. Srilaxmi, P., Sareddy, G. R., Setty, O. H., \& Babu, P. P. (2010). Protective efficacy of natansnin, a dibenzoyl glycoside from Salvinia natans against $\mathrm{CCl} 4$ induced oxidative stress and cellular degeneration in rat liver. $B M C$ pharmacology, 10(1), 13.

28. Arneson, W. L., \& Brickell, J. M. (2007). Clinical Chemistry: a laboratory perspective. FA Davis.

29. Akindele, A. J., Adeneye, A. A., Salau, O. S., Sofidiya, M. O., \& Benebo, A. S. (2014). Dose and time-dependent sub-chronic toxicity study of hydroethanolic leaf extract of Flabellaria paniculata Cav.(Malpighiaceae) in rodents. Frontiers in pharmacology, 5, 78 .

30. OO, A., Akindele, A. J., \& Nwumeh, K. I. (2010). Acute and subchronic toxicological assessment of Byrsocarpus coccineus Schum. and Thonn.(Connaraceae) aqueous leaf extract. 